Agrovoc descriptors: glycine max, soybeans, selenium, foliar application, fluorescence, chlorophylls, nutrient transport, respiration

Agris category code: F62

\title{
Selenium induced lower respiratory potential in Glycine max (L.) Merr.
}

\author{
Špela MECHORA ${ }^{1}$, Mateja GERM²
}

Received Nov. 24, 2009; accepted Jan. 18, 2010.

Delo je prispelo 24. novembra 2009, sprejeto 18. januarja 2010.

\begin{abstract}
Effect of selenium (Se) was studied in soybean (Glycine max (L.) Merr.) cv. Olna in Ljubljana, Slovenia. Se was added to plants as foliary spraying. Quantum yield of photosystem II (PSII) and respiratory potential measured as ETS activity of mitochondria were measured two times in the growing season. Respiratory potential was higher in young plants compared to mature plants. Se induced the lowering of respiratory potential. Addition of Se had no effect on quantum yield of photosystem II.
\end{abstract}

Key words: chlorophyll $a$ fluorescence, electron transport system activity, Glycine max, selenium

\section{IZVLEČEK}

\author{
VPLIV SELENA NA NIŽANJE DIHALNEGA
}

POTENCIALA PRI SOJI (Glycine max (L.) Merr.)

\begin{abstract}
Preučevali smo vpliv selena na fiziološke lastnosti soje (Glycine max (L.) Merr.) cv. Olna. Rastline so bile foliarno gnojene $\mathrm{s}$ selenom. Meritve fotosintezne učinkovitosti in respiratornega potenciala so bile opravljene dvakrat $\mathrm{v}$ rastni sezoni. Respiratorni potencial, merjen s pomočjo aktivnosti terminalnega elektronskega sistema je bil višji pri mladih rastlinah. Respiratorni potencial je bil nižji pri rastlinah, foliarno gnojenih $\mathrm{s}$ selenom $\mathrm{v}$ primerjavi $\mathrm{s}$ kontrolo. Fotosintezna učinkovitost ni bila odvisna od obravnavanja $\mathrm{s}$ selenom.
\end{abstract}

Ključne besede: aktivnost elektronskega transportnega sistema, Glycine max, fluorescenca klorofila $a$, selen

\begin{abstract}
Abbreviations - Okrajšave: ETS - electron transport system; $\mathrm{F}_{0}$ - minimal chlorophyll $a$ fluorescence yield in dark adapted samples; $\mathrm{F}_{\mathrm{m}}$ - maximal chlorophyll $a$ fluorescence yield in dark adapted samples; Fm' - the maximal fluorescence of an illuminated sample; $\mathrm{F}_{\mathrm{v}}$ - variable fluorescence; INT - iodo-nitro-tetrazolium-chloride; PPFD - photosynthetic photon flux density; PSII - photosystem II.
\end{abstract}

\section{INTRODUCTION}

Selenium (Se) is a naturally occurring trace element found in the Earth's crust, soils and minerals (Simmons and Wallschläger, 2005). It is an essential trace nutrient important to humans and animals, whose deficiency and toxic concentrations are very close to each other (Navarro-Alacron and Cabrera-Vique, 2008). Se has been recognized as an integral component of different enzymes, such as glutathione peroxidase and thioredoxin reductase (Birringer et al., 2002). Chemically it is similar to sulphur (S), leading to nonspecific replacement of $\mathrm{S}$ by $\mathrm{Se}$ in proteins and other sulphur components (Nowak et al., 2004). This results in non-functional proteins and enzymes.

In plants, Se functions as an antioxidant (Hartikainen, 2000). Plants take up Se from the soil primarily as selenate $\left(\mathrm{SeO}_{4}{ }^{2-}\right)$ or selenite $\left(\mathrm{SeO}_{3}{ }^{2-}\right)$ (Ellis and Salt, 2003). Se can increase the tolerance of plants to UVinduced oxidative stress, delay senescence and promote the growth of ageing seedlings (Xue et al., 2001).

\footnotetext{
${ }^{1}$ Department of Biology, Biotechnical Faculty, Večna pot 111, SI-1000 Ljubljana, Slovenia, e-mail: spela.mechora@bf.uni-lj.si

${ }^{2}$ Department of Biology, Biotechnical Faculty, Večna pot 111, SI-1000 Ljubljana, Slovenia
} 
In Se rich areas plants that accumulate large amounts of $\mathrm{Se}$ are found. They are called accumulators. Actively growing tissues usually contain the largest amounts of Se (Kahakachchi et al., 2004). Astragalus bisulcatus is reported to be the best Se accumulator. However, when absorbed in higher concentrations, Se can be harmful and catalyse the oxidation of thiols and simultaneously generate superoxide $\left(\mathrm{O}_{2}{ }^{-}\right)$, which means it acts as a prooxidant (Stewart et al., 1999).

The availability of Se for plants depends on soil properties including $\mathrm{pH}$, salinity and the content of $\mathrm{CaCO}_{3}$ (Kabata Pendias, 2001). Temperature is also important factor affecting Se availability. In soils low with Se, plants absorb more Se at temperature higher than $20^{\circ} \mathrm{C}$. Plants from arid regions have more Se in their tissues as those from wet regions.

Se content of soils ranges from deficit quantities of 0.01 $\mathrm{mg} \mathrm{kg}^{-1}$ at the Russian Plane to heavily toxic values of $1200 \mathrm{mg} \mathrm{kg}^{-1}$ in organic soils at Meath, Ireland (Nowak et al., 2004). Slovenian soils are poor with Se (Kreft et al., 2002). In acid soils Se is mainly present in form of selenite, which has very low solubility and plant aviability. In alkaline soils, $\mathrm{Se}$ is oxidized to selenate, which is more soluble and more available for uptake (Navarro-Alacron and Cabrera-Vique, 2008).

Se levels in soil generally reflect its presence in food and Se levels consumed by human populations. Deficiency of $\mathrm{Se}$ can cause a heart disease, hypothyroidism and a weakened immune system (Ellis and Salt, 2003). Kahakachchi et al. (2004) reported that Se has a cancer chemopreventive properties for humans. The daily intake of Se depends on its concentration level in food and on the amount of food consumed. The recommended intake is $80 \mu \mathrm{g}$ /day for men and 55 $\mu \mathrm{g} /$ day for women (National Research Council, 2000). Plants, which accumulate Se, may be useful as a "Sedelivery system" to supplement the mammalian diet in many areas that are deficient in Se (Terry et al., 2000).
Seed soaking or spraying of plants with Se solution may enrich the utilisable plant parts with Se compounds in concentrations of nutritional importance (Germ et al., 2007).

Glycine $\max (\mathrm{L}$.) Merr. (soybean) is one of the most important crops. It is one of the most important vegetables for dietary purposes. It is a member of the pea family (Fabaceae). Soybean plants height is from $20 \mathrm{~cm}$ to $2 \mathrm{~m}$. Steam, leaves and fruit are covered with hairs, which protect plants against drought. The leaves are trifoliolate. The fruit grows in clusters. Seeds contain very high levels of protein, including all essential amino acids (Nenadić, 1985).

The general metabolic activity of individual organisms can be assessed from terminal electron transport system (ETS) activity in mitochondria. Under stress condition organisms increase their need for energy. The ability to cope with stress in vital plants is therefore related to respiratory potential (ETS activity) of certain tissue. When stress is too big, the antioxidant metabolism is defeated. Strong stress causes reduced vitality of tissue, that reflects in lower respiratory potential (Germ and Gaberščik, 2003).

Lower photosynthetic activity could be a consequence of low photochemical efficiency of PSII, as shown by its lower quantum yield (Pieters and El Souki, 2005). Photochemical quantum yield of PSII is a measure of stress in plants. Any deviation from the maximum quantum yield may be considered as an integrative measure of stress to which a sample is exposed in a given situation (Schreiber et al., 1995).

The aim of present work was to study the influence of $\mathrm{Se}$ on the respiratory potential and quantum yield of photosystem II (PSII) in soybean.

\section{MATERIALS AND METHODS}

\section{Plant Material and Growth Conditions}

Soybean (Glycine max (L.) Merr.) cv. Olna plants were grown outdoors in Ljubljana, Slovenia (320 m above sea level, 46 $35^{\prime}$ $\left.\mathrm{N}, 14^{\circ} 55^{\prime} \mathrm{E}\right)$, in a Se-poor soil. Plants emerged on May 21, 2005 and were foliary sprayed with an aqueous solution containing $10 \mathrm{mg} \mathrm{Se} / \mathrm{L}$ in the form of $\mathrm{Na}$ selenate on June 5 . Fluorescence and ETS measurements were performed on $13^{\text {th }}$ of June and $20^{\text {th }}$ of July, $1^{\text {st }}$ and $26^{\text {th }}$ of July 2005 , respectively.

\section{ETS activity}

The respiratory potential of mitochondria was measured in plants via terminal electron transport system (ETS) activity as described by Packard (1971) and Kenner and Ahmed (1975). Plant material was homogenised in an ice-cold homogenisation buffer and sonicated with an ultrasound homogeniser $(40 \mathrm{~W}, 4710$, Cole-Parmer, Vernon Hills, IL, USA). The homogenate was than centrifuged $(8500 \times \mathrm{g}, 4 \mathrm{~min}$, $0{ }^{\circ} \mathrm{C}$ ) in a top refrigerated ultracentrifuge. $1.5 \mathrm{~mL}$ of substrate solution and $0.5 \mathrm{~mL}$ of iodo-nitro-tetrazolium-chloride (INT) were added to triplicates of the supernatant $(0.5 \mathrm{~mL})$ and incubated at $20{ }^{\circ} \mathrm{C}$ for $40 \mathrm{~min}$. During the incubation, INT instead of oxygen was reduced to formazan. After stopping the reaction with a stopping solution (formaldehyde and phosphoric acid, 1:1), the formazan absorption at $490 \mathrm{~nm}$ was determined. ETS activity was measured as the rate of tetrazolium dye reduction, and converted to equivalent oxygen as described by Kenner and Ahmed (1975). 


\section{Photochemical efficiency}

Chlorophyll fluorescence was measured in situ using a fluorometer (OS-500, Opti-Sciences, Tyngsboro, MA, USA). The potential quantum yield was evaluated in terms of the ratio $\mathrm{F}_{\mathrm{v}} / \mathrm{F}_{\mathrm{m}}$. Measurement of minimal $\left(\mathrm{F}_{0}\right)$ and maximal $\left(\mathrm{F}_{\mathrm{m}}\right)$ chlorophyll fluorescence were made after $15 \mathrm{~min}$ of darkness, provided by dark-adaptation clips. Fluorescence was excited with a saturating beam of "white light" (PPFD $=8000 \mu \mathrm{mol}$ $\mathrm{m}^{-2} \mathrm{~s}^{-1}, 0.8 \mathrm{~s}$ ). With a saturating pulse of "white light" (PPFD $=9000 \mu \mathrm{mol} \mathrm{m} \mathrm{m}^{-2} \mathrm{~s}^{-1}, 0.8 \mathrm{~s}$ ) the effective quantum yield was determined. The yield coefficient was defined as $\mathrm{Y}=\left(\mathrm{F}_{\mathrm{m}}{ }^{\prime}\right.$ $\left.\mathrm{F}_{0}{ }^{\prime}\right) / \mathrm{F}_{\mathrm{m}}{ }^{\prime}$, where $\mathrm{F}_{\mathrm{m}}{ }^{\prime}$ is the maximum and $\mathrm{F}_{0}{ }^{\prime}$ the minimum fluorescence of an irradiated sample (Schreiber et al., 1995).

\section{Statistical Analysis}

The data were evaluated by ANOVA (Statgraphics Version 4) and significance accepted at $\mathrm{p}<0.05$.

\section{RESULTS}

The effects of Se were studied in soybean plants.

Se exerted no effect on potential or effective photochemical quantum yield of PSII (Table 1). The values of potential as well as effective photochemical efficiency were very similar comparing control and Se treated plants. ANOVA test showed no statistical significant difference between control and Se treated plants at the $95 \%$ confidence level. Values of $F_{v} / F_{m}$ were close to 0.8 , which indicates the plant vitality.

ETS activity of untreated and treated plants was higher in the first measurement, comparing to the second measurement. Foliar treatment with Se had an effect on the ETS activity in soybean plants (Figure 1). Compared to the untreated plants, treated plants had lower ETS activity. ANOVA test revealed statistical significant difference between control and Se treated plants at the $95 \%$ confidence level.
Table 1. Potential $-F_{v} / F_{m}$ and effective $-\Delta F / F_{m}{ }^{\prime}$ photochemical quantum yield of PSII on $13^{\text {th }}$ of June and on $20^{\text {th }}$ of July 2005 . Se 0 - control, without added Se, Se1 - with added Se. Means \pm SD $(n=5-14)$.

\begin{tabular}{rrr}
\hline & $\mathbf{1 3 . 6 .}$ & $\mathbf{2 0 . 7 .}$ \\
\hline & $\mathbf{F v} / \mathbf{F m}$ \\
Se0 & $0.73 \pm 0.03$ & $0.69 \pm 0.07$ \\
Se1 & $0.75 \pm 0.03$ & $0.66 \pm 0.05$ \\
& & \\
& $\mathbf{\Delta F} / \mathbf{F m} \mathbf{\prime}^{\prime}$ & \\
Se0 & & \\
Se1 & $0.28 \pm 0.06$ & $0.42 \pm 0.08$ \\
\hline
\end{tabular}

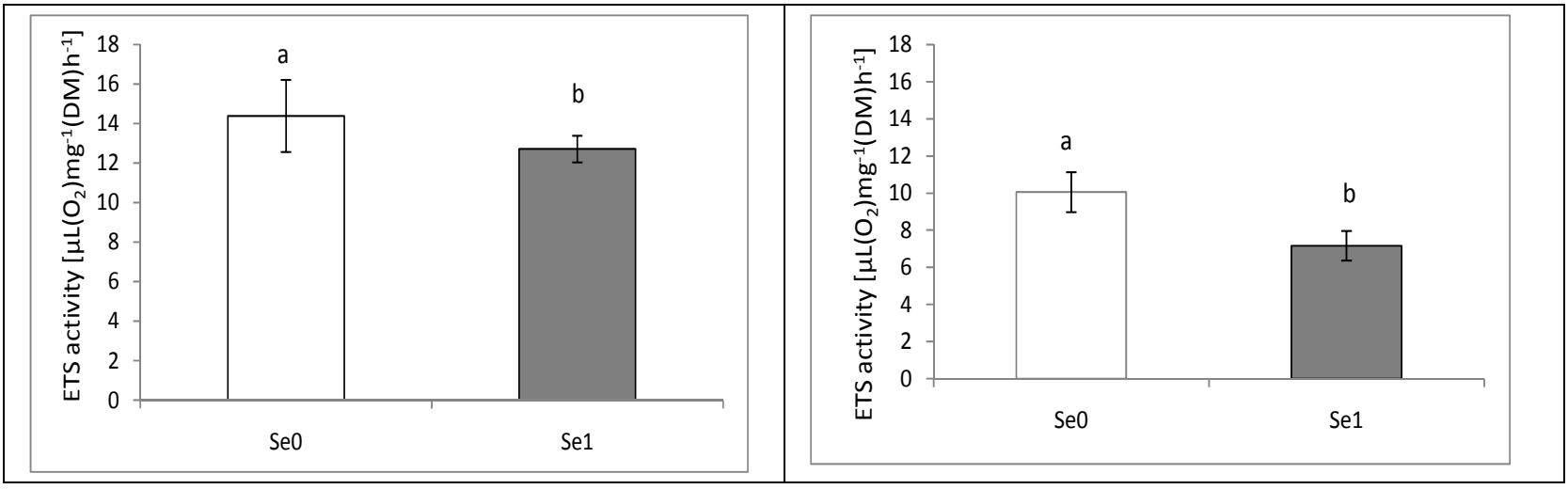

Figure 1. Terminal electron transport system (ETS) activity on $1^{\text {st }}$ (left panel) and on $26^{\text {th }}$ (right panel) of July 2005 . White - control, without added Se, gray - with added Se. Means \pm SD ( $n=4)$.

\section{DISCUSSION}

Selenium exerted no influence on potential $\left(\mathrm{F}_{\mathrm{v}} / \mathrm{F}_{\mathrm{m}}\right)$ or effective $\left(\Delta \mathrm{F} / \mathrm{F}_{\mathrm{m}}{ }^{\prime}\right)$ photochemical quantum yield of PSII (Table 1). For the purpose of comparison we made a table of Se impact taken from other studies (Table 2). It comprises the impact of selenium and its species on physiological parameters in leaves of different plants. Our results were in agreement with results obtained for common buckwheat (Tadina et al., 2007), chicory 
(Germ et al., 2007) and Cucurbita pepo (Germ et al., 2005), as shown in this table (Table 2). Values of $F_{v} / F_{m}$ were close to 0.8 , which indicate an undamaged antenna complex (Bischof et al., 1998). The effective quantum yield was lower than the potential quantum yield of PSII. Germ and co-workers (2007) report, that the values of potential photochemical efficiency close to the theoretical maximum indicate reversible disturbance rather than damage to the reaction centre.

Terminal electron transport system activity was higher at the beginning of the growth period, because plants needed more energy during intensive growth in order to develop essential structural components (Figure 1). Smillie (1962) reports the decreasing of respiratory rates of pea leaves during leaf development. Author suggests that this may be a result of decreasing ability of the cells to use fully their potential enzymic capacity, or it may be the direct consequence of a decrease in the respiratory enzymic capacity of the leaf. Higher ETS activity in young plants comparing to mature plants were also reported for Fagopyrum esculentum and F. tataricum (Breznik et al., 2005; Tadina et al., 2007), for Pisum sativum (Smrkolj et al., 2006), and for Potamogeton crispus (Mazej and Gaberščik, 1999). ETS activity is a measure of the metabolic potential of organisms and vary among plant species.

ETS activity was lower in plants, treated with Se in both measurements (Figure 1). The opposite results are given by Germ and Osvald (2005) for Eruca sativa. ETS activity was higher in Se-treated plants as well in some other plants (Table 2). Increased ETS activity indicates that plants are under stress. When the stress is too strong and plants cannot cope with it any more, the respiratory potential drops (Ožbolt et al., 2008), as shown in Figure 1. However, potential photochemical efficiency of PSII in soybean was close to 0.8 in Se treated and untreated plants. This indicated that Se negatively affected respiratory chain but not photosynthetic processes.

Table 2. Literature data on impact of selenium and its species on physiological parameters in leaves of different plants.

\begin{tabular}{|c|c|c|c|c|c|}
\hline Plant & Se concentration & $\begin{array}{l}\text { Way of application } \\
\text { of Se }\end{array}$ & Parameter & Effects Se & Literature \\
\hline \multirow{2}{*}{$\begin{array}{l}\text { Fagopyrum } \\
\text { esculentum } \\
\text { F. tataricum }\end{array}$} & \multirow[t]{2}{*}{$1 \mathrm{~g} \mathrm{Se}$} & \multirow[t]{2}{*}{ Foliar spray } & $\mathrm{Fv} / \mathrm{Fm}$ & - & \multirow{2}{*}{$\begin{array}{l}\text { Breznik et al., } \\
2005\end{array}$} \\
\hline & & & $\Delta \mathrm{F} / \mathrm{F}_{\mathrm{m}}{ }^{\prime}$ & $\uparrow$ & \\
\hline \multirow{3}{*}{ Cichorium intybus } & \multirow[t]{3}{*}{$1 \mathrm{mg} \mathrm{Se} / \mathrm{L}$} & \multirow[t]{3}{*}{ Foliar spray $2 \mathrm{x}$} & $\mathrm{Fv} / \mathrm{Fm}$ & - & \multirow{3}{*}{$\begin{array}{l}\text { Germ et al., } \\
2007\end{array}$} \\
\hline & & & $\Delta \mathrm{F} / \mathrm{F}_{\mathrm{m}}{ }^{\prime}$ & - & \\
\hline & & & ETS & $\uparrow$ & \\
\hline $\begin{array}{l}\text { Fagopyrum } \\
\text { esculentum }\end{array}$ & $10 \mathrm{mg} \mathrm{Se} / \mathrm{L}$ & Soaked seeds & ETS & $\downarrow$ & Germ, 2006 \\
\hline Cucurbita pepo & $1.5 \mathrm{mg} \mathrm{Se} / \mathrm{L}$ & Foliar spray & ETS & $\downarrow$ & Germ, 2005 \\
\hline \multirow{3}{*}{$\begin{array}{l}\text { Fagopyrum } \\
\text { esculentum }\end{array}$} & \multirow[t]{3}{*}{$1 \mathrm{~g} \mathrm{Se}$} & \multirow[t]{3}{*}{ Foliar spray } & $\mathrm{Fv} / \mathrm{Fm}$ & - & \multirow{3}{*}{$\begin{array}{l}\text { Tadina et al., } \\
2007\end{array}$} \\
\hline & & & $\Delta \mathrm{F} / \mathrm{Fm}^{\prime}$ & - & \\
\hline & & & ETS & $\downarrow$ & \\
\hline Pisum sativum & $10 \mathrm{mg} \mathrm{Se}$ & Foliar spray $1 \mathrm{x}, 2 \mathrm{x}$ & ETS & $\uparrow(2 \mathrm{x})$ & $\begin{array}{l}\text { Smrkolj et al., } \\
2006\end{array}$ \\
\hline \multirow[t]{3}{*}{ Cucurbita pepo } & \multirow[t]{3}{*}{$1.5 \mathrm{mg} \mathrm{Se} / \mathrm{L}$} & \multirow[t]{3}{*}{ Foliar spray } & $\mathrm{Fv} / \mathrm{Fm}$ & - & \multirow{3}{*}{$\begin{array}{l}\text { Germ et al., } \\
2005\end{array}$} \\
\hline & & & $\Delta \mathrm{F} / \mathrm{F}_{\mathrm{m}}{ }^{\prime}$ & - & \\
\hline & & & ETS & $\uparrow$ & \\
\hline \multirow[t]{3}{*}{ Eruca sativa } & \multirow[t]{3}{*}{$10 \mathrm{mg} \mathrm{Se} / \mathrm{L}$} & \multirow[t]{3}{*}{ Soaked seeds } & $\mathrm{Fv} / \mathrm{Fm}$ & $\uparrow$ & \multirow{3}{*}{$\begin{array}{l}\text { Germ and } \\
\text { Osvald, } 2005\end{array}$} \\
\hline & & & $\Delta \mathrm{F} / \mathrm{F}_{\mathrm{m}}{ }^{\prime}$ & - & \\
\hline & & & ETS & $\uparrow$ & \\
\hline \multirow{3}{*}{$\begin{array}{l}\text { Solanum } \\
\text { tuberosum }\end{array}$} & \multirow[t]{3}{*}{$10 \mathrm{mg} \mathrm{Se} / \mathrm{L}$} & \multirow[t]{3}{*}{ Foliar spray } & $\mathrm{Fv} / \mathrm{Fm}$ & $\uparrow$ & \multirow{3}{*}{$\begin{array}{l}\text { Germ et al., } \\
2007\end{array}$} \\
\hline & & & $\Delta \mathrm{F} / \mathrm{F}_{\mathrm{m}}{ }^{\prime}$ & $\uparrow$ & \\
\hline & & & ETS & $\bar{\uparrow}$ & \\
\hline $\begin{array}{l}\text { Fragaria } \mathrm{x} \\
\text { ananassa } \\
\text { Hordeum vulgare }\end{array}$ & $\begin{array}{l}0.1 \mathrm{mg} \mathrm{Se} / \mathrm{L} \\
1 \mathrm{mg} \mathrm{Se} / \mathrm{L}\end{array}$ & Foliar spray & $\mathrm{Fv} / \mathrm{Fm}$ & $\uparrow$ & $\begin{array}{l}\text { Valkama, } \\
2003\end{array}$ \\
\hline
\end{tabular}

Legend: $\uparrow$ - increased, $\downarrow$ - decreased, - no effect, $1 \mathrm{x}$ - once foliary sprayed, $2 \mathrm{x}$ - twice foliary sprayed. 


\section{ACKNOWLEDGEMENT}

This research was financed by the Ministry of Higher Education, Science and Technology of the Republic of Slovenia through the programs "Biology of plants" (P1-
0212), "Young researchers" (32059) and the project (J42041).

\section{REFERENCES}

Birringer M., Pilawa S., Flohč L. 2002. Trends in selenium biochemistry. Nat. Prod. Rep. 19: 693-718.

Bischof K., Hanelt D., Wiencke C. 1998. UV-radiation can affect depth-zonation of Antarctic macroalgae. Mar. Biol. Berlin 131: 597-605.

Breznik B., Germ M., Gaberščik A., Kreft I. 2005. Combined effects of elevated UV-B radiation and the addition of selenium on common (Fagopyrum esculentum Moench) and tartary (Fagopyrum tataricum (L.) Gaertn.) buckwheat. Photosyntetica 43-4: 583-589.

Ellis D.R., Salt D.E. 2003. Plants, selenium and human health. Curr. Opin. Plant Biol. 6: 273-279.

Germ M., Gaberščik A. 2003. Dihalni potencial - kazalnik stresa pri rastlinah. Zb. Bioteh. Fak. Univ. Ljublj. Kmet. 81-2: 335-339.

Germ M., Osvald J. 2005. Selenium treatment affected respiratory potential in Eruca sativa. Acta agriculturae Slovenica 85-2: 329 - 335 .

Germ M. 2005. Combined impact of solar UV-B radiation and selenium treatment on respiratory potential in pumpkins (Cucurbita pepo L.). Acta agriculturae Slovenica 85-2: 337-342.

Germ M., Kreft I., Osvald J. 2005. Influence of UV-B exclusion and selenium treatment on photochemical efficiency of photosystem II, yield and respiratory potential in pumpkins (Cucurbita pepo L.). Plant physiol. Biochem. 43: 445-448.

Germ M. 2006. The effect of UV-B radiation and selenium on respiratory potential in common buckwheat (Fagopyrum esculentum). Fagopyrum 23: 91-93.

Germ M., Stibilj V., Osvald J., Kreft I. 2007. Effects of selenium foliar application on chicory (Cichorium intybus L.). J. of Agric. Food Chem. 55: 795-798.

Germ M., Kreft I., Stibilj S., Urbanc-Berčič O. 2007. Combined effects of selenium and drought on photosynthesis and mitochondrial respiration in potato. Plant Physiol. Biochem. 45: 162-167.

Germ M. 2008. The response of two potato cultivars on combined effects of selenium and drought. Acta agriculturae Slovenica 91-1: 121-137.

Germ M., Stibilj V., Kreft S., Gaberščik A., Pajk F., Kreft I. 2009. Selenium concentration in St. John's wort (Hypericum perforatum L.) herb after foliar spraying of young plants under different UV-B radiation levels. Food Chem. 117: 204-206.
Hartikainen H., Xue T., Piironen V. 2000. Selenium as an antioxidant and prooxidant in ryegrass. Plant. Soil. 225: 193-200.

Kabata Pendias A. 2001. Trace elements in soils and plants, 3rd edn. Boca Raton, FL, CRC Press: 241-252.

Kahakachchi C., Boakye H.T., Uden P.C., Tyson J.F. 2004 Chromatographic speciation of anionic and neutral selenium compounds in Se-accumulating Brasica juncea (Indian mustard) and in selenized yeast. Chromatogr. A 1054: 303-312.

Kenner R.A., Ahmed S.I. 1975. Measurements of electron transport activities in marine phytoplankton. Mar. Biol. 33: 119-127.

Kreft I., Stibilj V., Trkov Z. 2002. Iodine and selenium content in punpkin (Cucurbita pepo L.) oil and oil-cake. Eur. Food Res. Technol., 215: 279-281.

Mazej Z., Gaberščik A. 1999. ETS-activity as a measure of vitality of different macrophyte species. 2nd Slovenian Symposium on Plant Physiology with international participation / issue editors Vilhar B., Grill D., Guttenberger H. Apud Ferdinandum Berger \& Fil. 39-3: 181-185.

National Research Council, Recommended Dietary Allowances, National Academy Press, Washington, DC, 2000.

Navarro-Alarcon M., Cabrera-Vique C. 2008. Selenium in food and the human body: A review. Sci. Tot. Environ. 400: 115-141.

Nenadić N. 1985. Soja. Ljubljana, ČZP Kmečki glas.

Nowak J., Kaklewski K., Ligocki M. 2004. Influence of selenium on oxidoreductive enzymes activity in soil and in plants. Soil Biol. Biochem., 36: 1553-1558.

Ožbolt L., Kreft S., Kreft I., Germ M., Stibilj V. 2008. Distribution of selenium and phenolics in buckwheat plants grown from seeds soaked in Se solution and under different levels of UV-B radiation. Food chem. 3-110: 691-696.

Packard T.T. 1971. The measurement of respiratory electrontransport activity in marine phytoplankton. J. Mar. Research 29: 235-243.

Pieters A.J., El Souki S. 2005. Effects of drought during grain filling on PS II activity in rice. J. Plant Physiol. 62: 903911.

Schreiber U., Bilger W., Neubauer C. 1995. Chlorophyll fluorescence as a nonintrusive indicator for rapid 
assessment of in vivo photosynthesis. - In: Schulze E.D., Caldwell, M.M. (ed.): Ecophysiology of Photosynthesis. pp. 49-70. Springer-Verlag, Berlin - Heidelberg - New York.

Simmons D.B.D., Wallschläger D. 2005. A critical review of the biogeochemistry and ecotoxicology of selenium in lotic and lentic environments. Environ. Toxicol Chem. 246: 1331-1343.

Smillie R.M. 1962. Photosynthetic and respiratory activities of growing pea leaves. Plant Physiol. 37: 716-721.

Smrkolj P., Germ M., Kreft I., Stibilj V. 2006. Respiratory potential and Se compounds in pea (Pisum sativum L.) plants grown from Se-enriched seeds. J. Exp. Bot. 57-1: 3595-3600.

Stewart M.S., Spallholz J.E., Neldner K.H., Pence B.C. 1999. Selenium compounds have disparate abilities to impose oxidative stress and induce apoptosis. Free Radic. Biol. Med. 26: 42-48.
Tadina N., Germ M., Kreft I., Breznik B., Gaberščik A. 2007. Effects of water deficit and selenium on common buckwheat (Fagopyrum esculentum Moench.) plants. Photosyntetica 45-3: 472-476.

Terry N., Zayed A., De Souza M.P., Tarun A.S. 2000. Selenium in higher plants. Annu. Rev. Plant Physiol. Plant Mol. Biol. 51: 401-432.

Valkama E., Kivimäenpää M., Hartikainen H., Wulff A. 2003. The combined effects of enhanced UV-B radiation and selenium on growth, chlorophyll fluorescence and ultrastructure in strawberry (Fragaria $\times$ ananassa) and barley (Hordeum vulgare) treated in the field. Agric. For. Meteor. 120: 267-278.

Xue T.L., Hartikainen H., Piironen V. 2001. Antioxidative and growth-promoting effects of selenium on senescing lettuce. Plant Soil 237: 55-61. 